\title{
A CUT MARKER FOR AIRCRAFT SEAT COVER
}

\author{
Sonja Jordeva ${ }^{1 *}$, Hristina Anusheva', Sashka Golomeova Longurova',

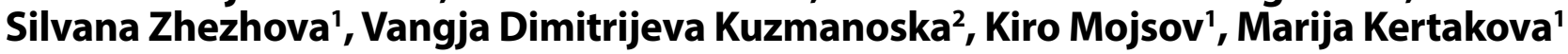

\author{
'University, "Goce Delchev", Shtip, Faculty of Technology \\ 2University, ",Goce Delchev", Shtip, Art Academy \\ Krste Misirkov 10-A, Shtip, Republic of North Macedonia \\ *e-mail: sonja.jordeva@ugd.edu.mk
}

\author{
Professional paper \\ UDC: 687.1:684.7
}

doi: $10.5937 /$ tekstind2102040J

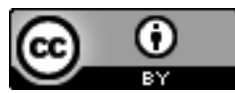

\begin{abstract}
A$ cut marker shows how pattern pieces should be cut from one or several layers of fabric and it has a direct impact on fabric consumption. In the confection industry besides clothes, items are made for other purposes. In this paper, an analysis of the making a cut marker for aircraft seat cover is made as well as a description of the materials needed. Aircraft seat cover is made from multilayer (laminated) materials and natural leather. Process of making the cut marker of headrest cover, the backrest cover and the legrest cover is especially considered in this paper. The cost of the material for the production of the aircraft seat cover is calculated with the help of the cut marker. The manufactured aircraft seat cover should be of top quality, which is an imperative today due to the serious competition in the market.
\end{abstract}

Keywords: aircraft seat, cover, sketch, cut marker.

\section{MARKER ZA KROJENJE NAVLAKE AVIONSKOG SEDIŠTA}

\begin{abstract}
Apstrakt: Marker za krojenje (linija krojenja) pokazuje kako treba iseći krojne delove iz jednog ili nekoliko slojeva tekstilnog materijala i ima direktan uticaj na potrošnju materijala. U konfekciskoj industriji, osim odeće, izrađuju se predmeti koji se koriste i u druge svrhe. U ovom radu je napravljena analiza izrade markera za krojenje navlake avionskog sedišta, a dat je i opis potrebnih materijala. Navlaka avionskog sedišta napravljena je od višeslojnih (laminiranih) materijala kao i od prirodne kože. U radu je detaljno razmatran postupak izrade markera za krojenje navlake naslona za glavu, naslona za leđa i za noge. Troškovi materijala za proizvodnju navlake avionskog sedišta izračunavaju se uz pomoć markera. Proizvedena navlaka avionskog sedišta mora biti vrhunskog kvaliteta, što je danas imperativ zbog ozbiljne konkurencije na tržištu.
\end{abstract}

Ključne reči: avionsko sedište, navlaka, skica, marker za krojenje.

\section{INTRODUCTION}

Making a cut marker is very important for the highest usage and lowest waste of fabric. The cut marker illustrates how pattern pieces of one or more garments should be cut from several layers of fabric. The person who arranges the marker is the marker planner. It is the marker planner's job to arrange the pattern pieces efficiently, wasting as little of the fabric as possible. The percentage of fabric cut into pieces is called the pattern yield (material utilization) [1]. The width of the marker depends on the width of the fabric roll which is typically assumed to be constant in many researches [2]. The different width of the textile rolls for the same work order that varies a few centimetres can be a problem for the technical preparation in the apparel industry around the width of the markers that need to be constructed. The length of each marker is restricted and generally depends on a planner or a cutting table length [3]. The choice of the type of cut marker depends on the type of the garment (or other item), the structure of the textile material and the size of the work order. An emphasis is placed on the marker utilization because of their important role in controlling material costs $[4,5]$.

In garment companies besides clothes, items are made for other purposes (seat covers, tents etc.) This paper is related to aircraft seat cover. There are several 
types of aircraft seat classes such as: economy class, premium economy class, business class (first class) and super first class. The quality of the airplane seat cover has a very big impact on flight comfort. In this paper, an analysis of the cut marker and the calculation of the material cost is made for aircraft seat cover for a Boeing 787 with a size for standard business class. Figure 1 shows the appearance of the airplane seat cover with its components: the headrest cover, the backrest cover and the legrest cover.

The aircraft seat covers can be made of wool blends, polyester, artificial leather and natural leather. The materials used can be laminated which allows more design options. Figure $1 \mathrm{~b}$ shows a cross section of the laminated cut part that can be composed of up to five layers of material. Laminated materials improve the comfort of the seat and its degree of rigidity. Depending on the type of seat, foam with the appropriate thickness is selected. The leather or the fabric is bonded with the help of the adhesive with $5 \mathrm{~mm}$ or $10 \mathrm{~mm}$ foam on one side. On the other side it is connected with the cotton knitted fabric with the help of the adhesive [6].

\section{EXPERIMENTAL}

\subsection{Sketches and description of the headrest cover, backrest cover and legrest cover}

Figures 2, 3 and 4 show the sketches of the headrest cover, backrest cover and legrest cover, where several views are presented from different angles of

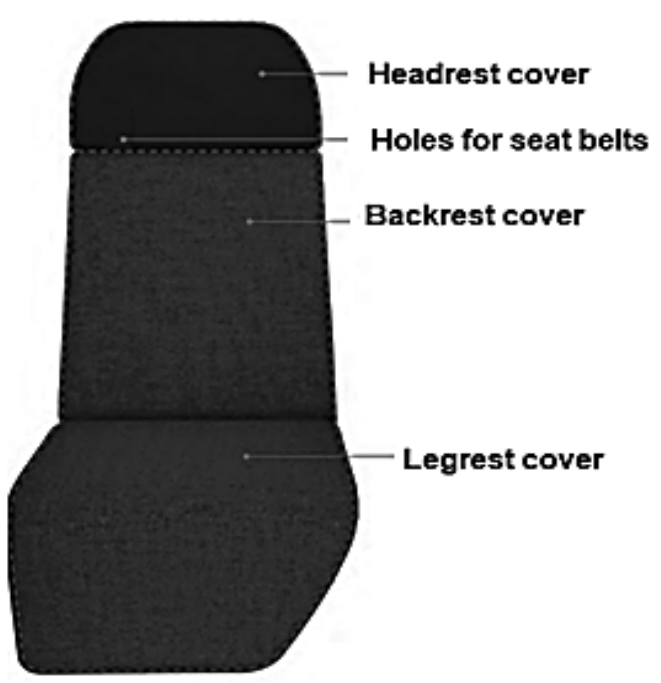

a) the cover (i.e., outside front view, outside top view, outside rear view, outside side view, inside rear view, inside front view). Table 1 shows the types of materials used in the manufacturing of the aircraft seat according to the sketches in Figures 2, 3 and 4. Table 2 describes the zones $A, B, C, D, E$ and $F$ which are marked in Figures 2, 3 and 4. These zones show how many layers of material the marked part of the cover is made of and in what order the different materials in the layers are arranged. Zone $\mathbf{A}$ of the headrest cover is composed of five layers of material arranged in the following order 1-3-4-3-2 (different numbers denote different types of material in Table 1, for example 1 denotes leather, 2 refers to cotton knitted fabric etc.). Seen from top to bottom, zone A of the headrest cover is composed of: the first layer is leather (1), then the adhesive (3) which binds the leather to the 5 $\mathrm{mm}$ foam (4), a layer of adhesive (3) which connects the $5 \mathrm{~mm}$ foam with cotton knitted fabric (2). Zone B is composed of three layers 5-1-8. The first layer of material of zone B is $25 \mathrm{~mm}$ black velcro smooth tape (5) which is sewn on the back of the leather (1) and on the face of the leather $25 \mathrm{~mm}$ black velcro rough tape (8) is sewn. Zone $\mathbf{C}$ is composed of two layers 1-9, leather (1) on which $20 \mathrm{~mm}$ black velcro smooth tape (9) is sewn on the back. Zone $\mathbf{D}$ is composed of two layers 9-1, $20 \mathrm{~mm}$ black velcro smooth tape (9) is sewn on the back of the leather (1). Zone $\mathbf{E}$ is composed of two layers 10-1 where $20 \mathrm{~mm}$ of black velcro rough tape (10) is sewn to the face of the leather (1). Zone $\mathrm{F}$ is composed of two layers 5-1, $25 \mathrm{~mm}$ black velcro smooth tape is sewn on the back of the leather. The same explanation applies to the zones for backrest and legrest covers (Table 2).

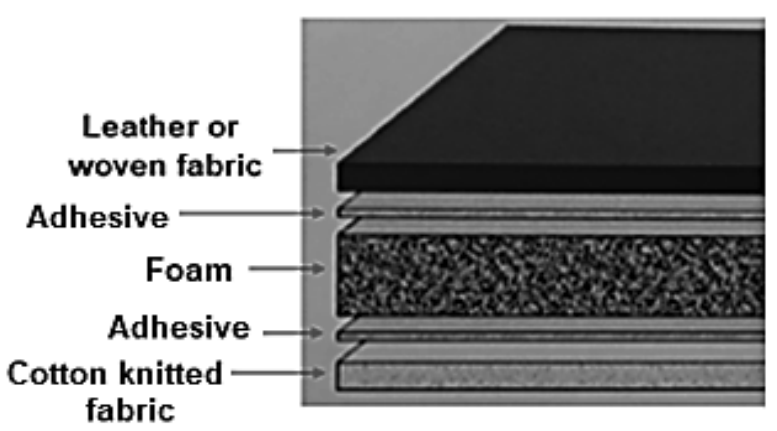

b)

Figure 1: Aircraft seat cover and cross section of the laminated part [6] 


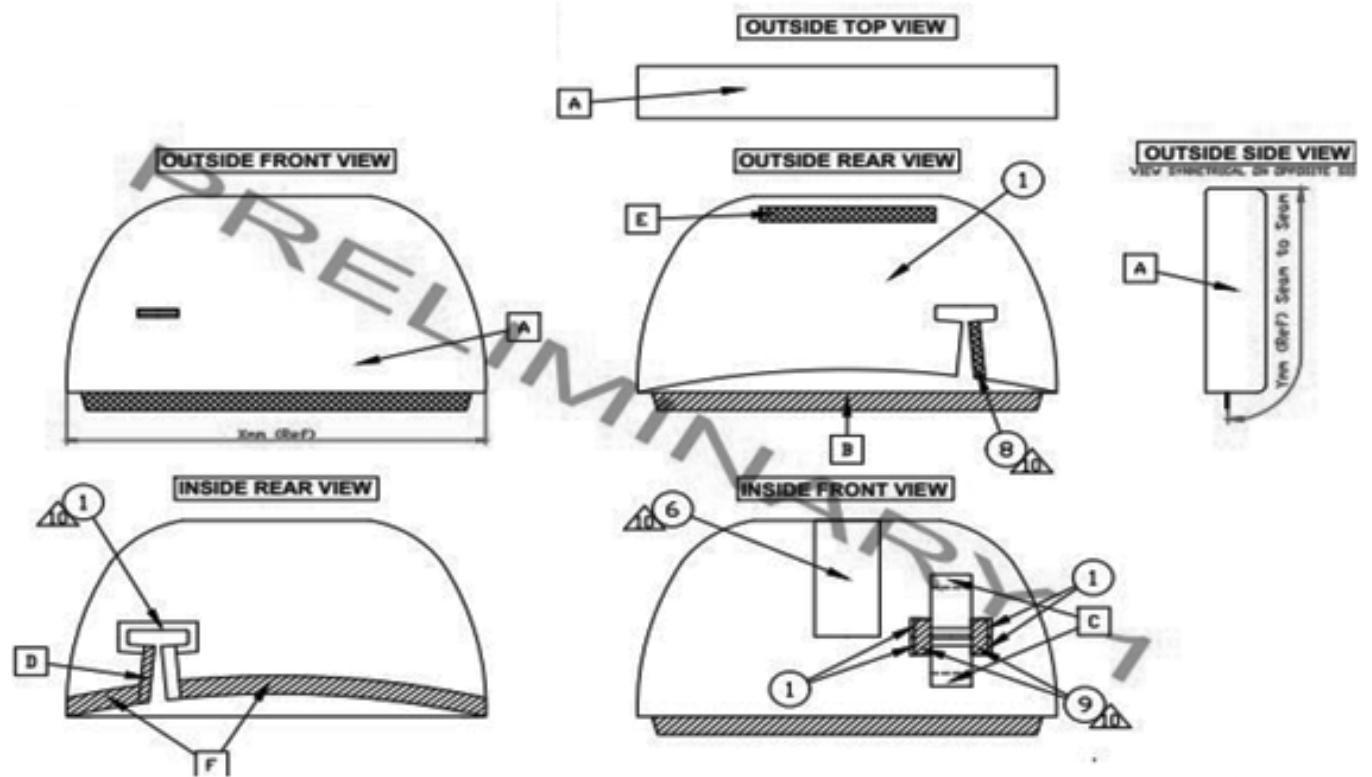

Figure 2: A sketch of headrest cover [6]

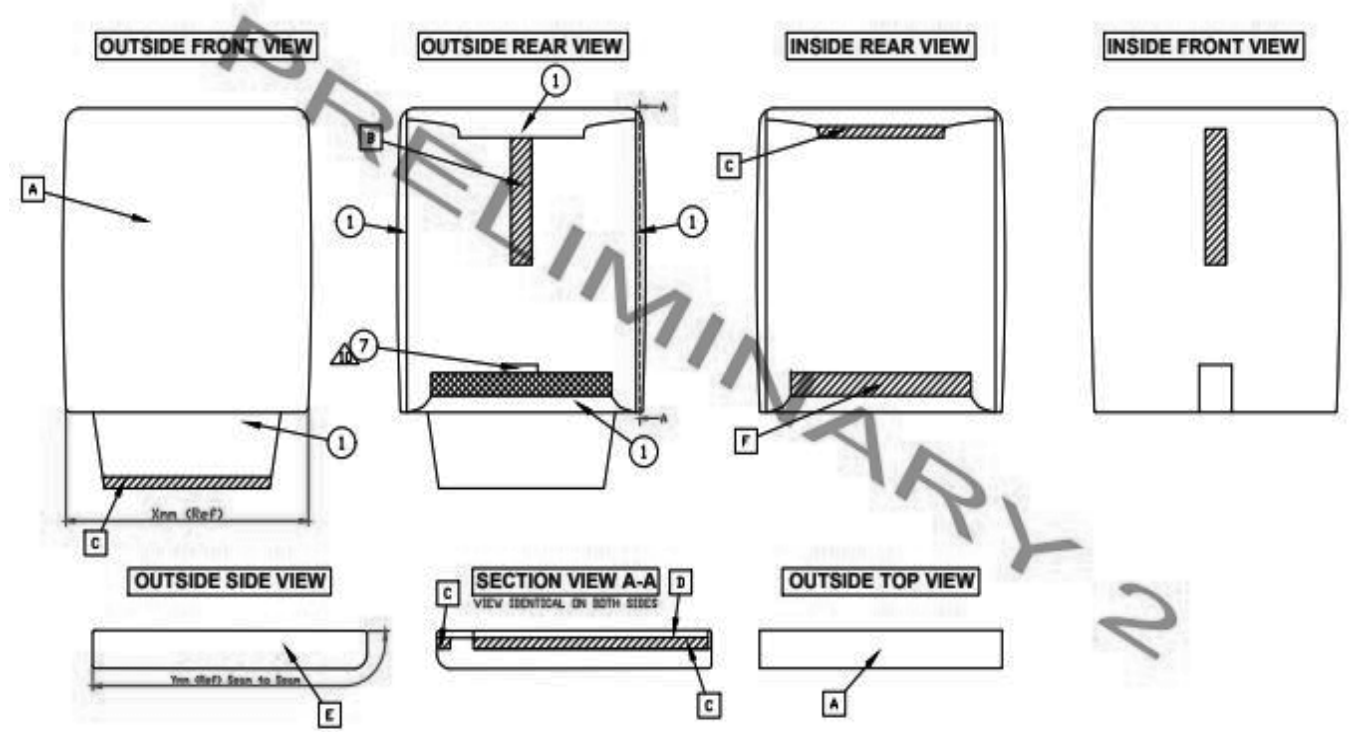

Figure 3: A sketch of headrest backrest cover [6]

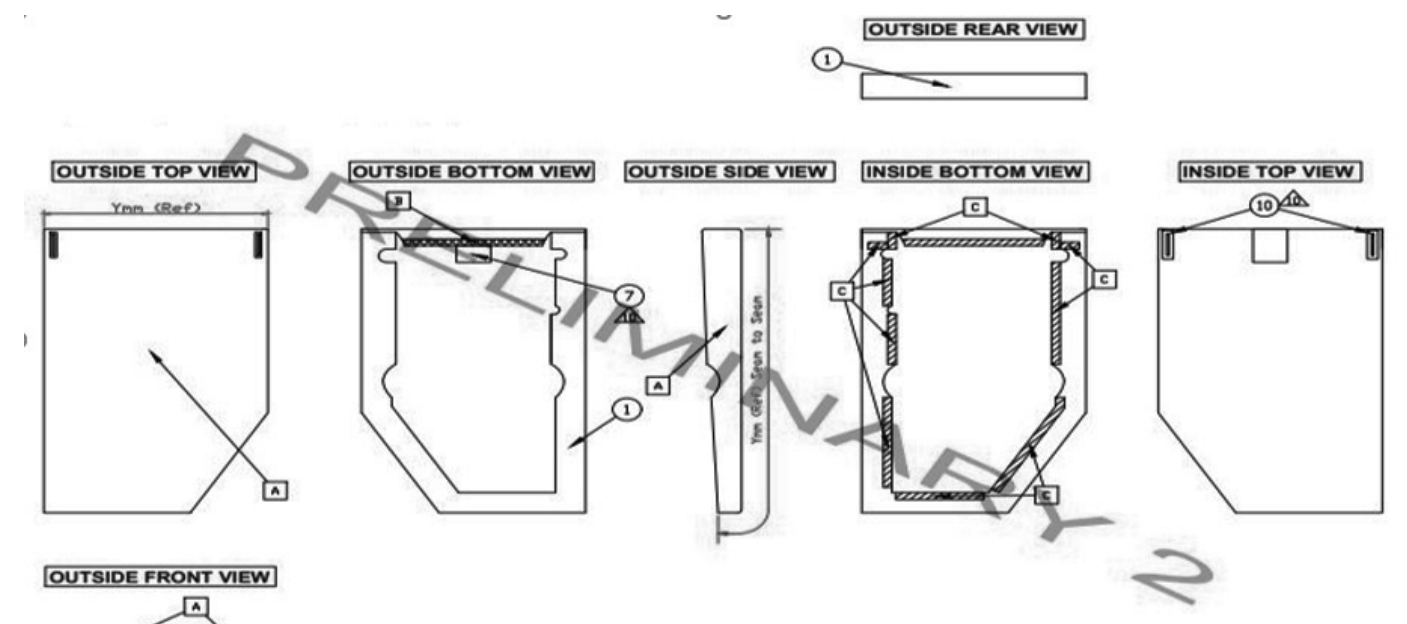

Figure 4: A sketch of legrest cover [6] 
Table 1: Types of materials

\begin{tabular}{|c|l|l|l|}
\hline \multicolumn{3}{|c|}{ Type of material } \\
\hline No. & Headrest Cover & Backest Cover & Legrest Cover \\
\hline 1 & Leather & Woven fabric & Woven fabric \\
\hline 2 & Cotton knitted fabric & Cotton knitted fabric & Cotton knitted fabric \\
\hline 3 & Adhesive & Adhesive & Adhesive \\
\hline 4 & Foam $5 \mathrm{~mm}$ & Foam $10 \mathrm{~mm}$ & Foam $5 \mathrm{~mm}$ \\
\hline 5 & $25 \mathrm{~mm}$ black velcro smooth tape & $25 \mathrm{~mm}$ black velcro smooth tape & $20 \mathrm{~mm}$ black velcro smooth tape \\
\hline 6 & Label & $50 \mathrm{~mm}$ black velcro smooth tape & $20 \mathrm{~mm}$ black velcro rough tape \\
\hline 7 & Black thread no.4000 /30 & Label & Label \\
\hline 8 & $25 \mathrm{~mm}$ black velcro smooth tape & Black thread no.4000 /30 & Black thread no.4000/30 \\
\hline 9 & $20 \mathrm{~mm}$ black velcro smooth tape & Black thread no.M75/overlok & Black thread no.M75/overlok \\
\hline 10 & $20 \mathrm{~mm}$ black velcro smooth tape & Foam $5 \mathrm{~mm}$ & Lining \\
\hline 11 & & $50 \mathrm{~mm}$ black velcro rough tape & Woven fabric \\
\hline
\end{tabular}

Table 2: Description of the zones in the headrest, backrest ang legrest cover sketch

\begin{tabular}{|c|c|c|c|c|c|c|c|c|c|c|c|c|c|c|c|c|}
\hline \multicolumn{10}{|c|}{ Layers of material } \\
\hline Zone & \multicolumn{10}{|c|}{ Headrest cover sketch } & \multicolumn{1}{|c|}{ Backrest cover sketch } & \multicolumn{5}{c|}{ Legrest cover sketch } \\
\hline A & 1 & 3 & 4 & 3 & 2 & 1 & 3 & 4 & 3 & 2 & & 1 & 3 & 4 & 3 & 2 \\
\hline B & 5 & 1 & 8 & & & 6 & 2 & 3 & 4 & 3 & 1 & 6 & 1 & 5 & & \\
\hline C & 1 & 9 & & & & 5 & 1 & & & & & 5 & 1 & & & \\
\hline D & 9 & 1 & & & & 1 & 5 & & & & & 1 & 3 & 4 & 3 & 2 \\
\hline E & 10 & 1 & & & & 1 & 3 & 10 & 3 & 2 & & 6 & 1 & 5 & & \\
\hline F & 5 & 1 & & & & 6 & 1 & 11 & & & & 5 & 1 & & & \\
\hline
\end{tabular}

\subsection{A cut marker for the headrest cover}

According to the sketch of the model, we move on to the stage of making pattern pieces (cutting parts) for headrest cover (Figure 5). Each part is marked with a number: 1-9, 2-9, 3-9,... and 9-9. If there are auxiliary points that need to be marked to help us in sewing precision, we must emphasize on which side we will mark the point, on the face or on the back of the leather.

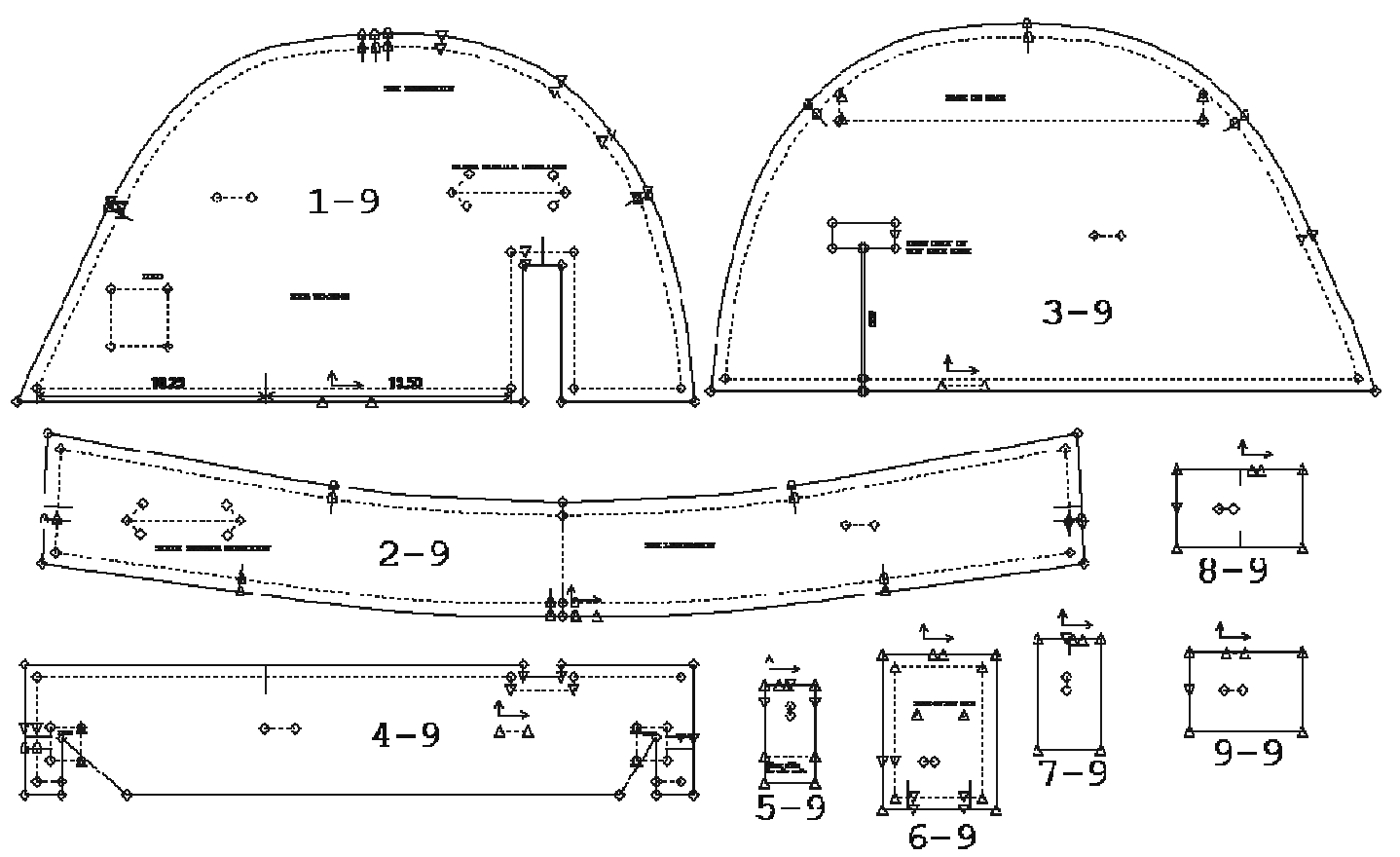

Figure 5: Cutting parts of the headrest cover [6] 

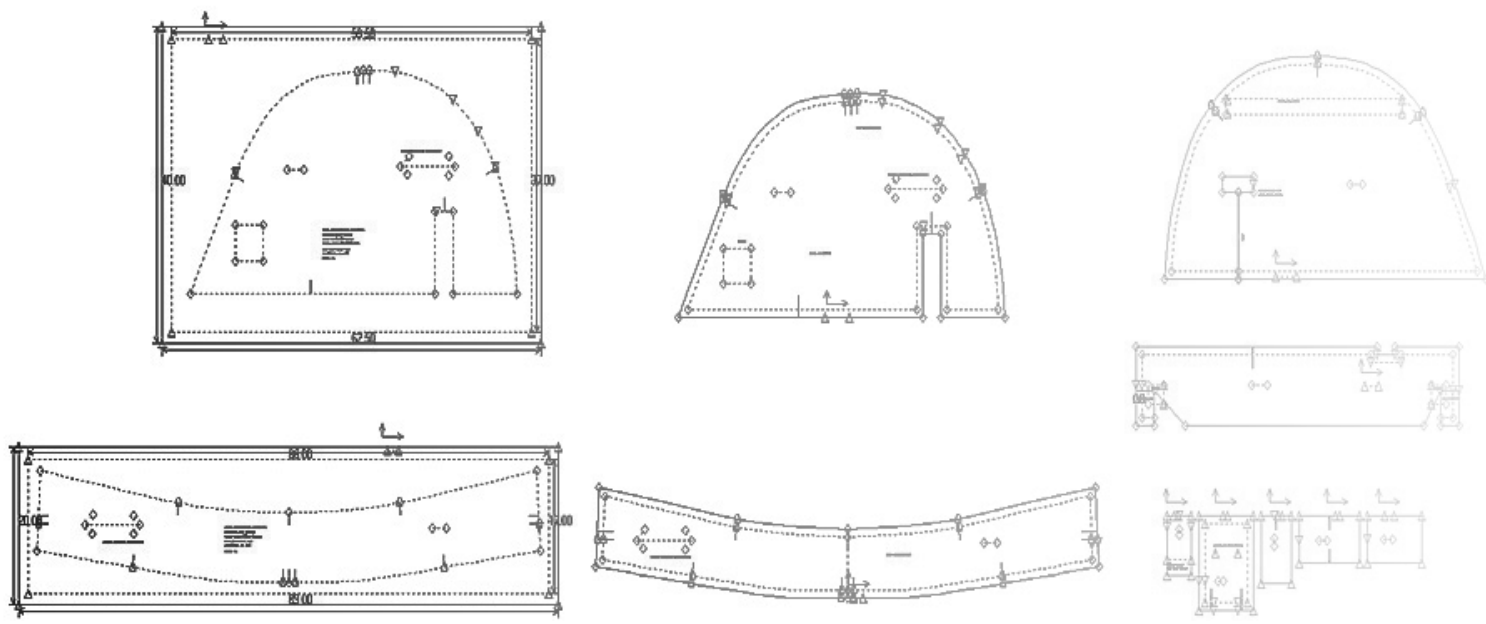

Figure 6: Auxiliary cut markers for cutting parts 1-9 and 2-9 on the headrest cover [6]

Cutting parts 1-9 and 2-9 are parts that need to be laminated before being cut. For them, special auxiliary cut markers (Figure 6 ) are made which will be used later in the calculation of material consumption. In these cut markers we mark the direction of stretching of the cotton knitted fabric, as well as the thickness of the foam ( $5 \mathrm{~mm}$ foam). The cut parts marked in blue (Figure 6) are not laminated (leather only), so they will later fit directly into the cut marker used to calculate leather consumption for the entire cover. The calculation of the material for making the headrest cover on the basis of the cut marker is made. In our case, this cover is made of three types of material: leather, foam and cotton knitted fabric. This means that three cut markers should be made: one for leather, another for foam and a third for knitted fabric. According to the cut marker from which the consumption of leather is calculated a piece of leather with dimensions $115 \times 60$ $\mathrm{cm}$ is needed. This cut marker includes two auxiliary cut markers and seven other parts which are made only of leather. A cut marker for a cotton knitted fabric covers only the auxiliary cut markers because only those two parts are laminated and contain cotton knitted fabric. This cut marker is $89 \times 60 \mathrm{~cm}$ in size. The parts marked in blue are not included because they are not laminated i.e. they do not contain cotton knitted fabric. According to the cut marker of the foam the material consumption is $86 \times 54 \mathrm{~cm}$.

\subsection{A cut marker for the backrest cover}

When the sketching is completed and the materials of which the individual zones are composed of are defined, the cutting parts of the backrest cover are made (Figure 7). The procedure is the same as for the headrest cover.

The cutting part 1-7 is a part that is laminated with $10 \mathrm{~mm}$ foam, while the cutting parts 2-7 and 3-7 are laminated with $5 \mathrm{~mm}$ foam. Special auxiliary cut markers are made for them which we will use later
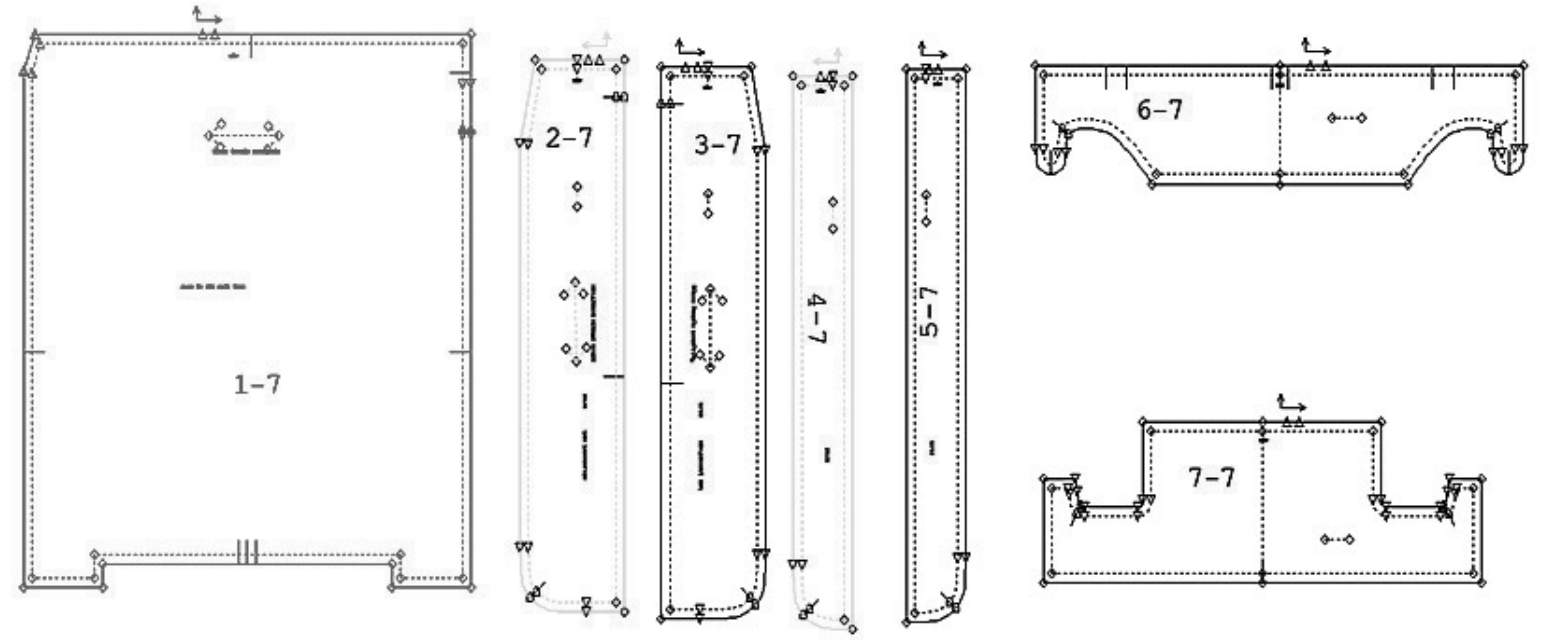

Figure 7: Cutting parts of the backrest cover [6] 


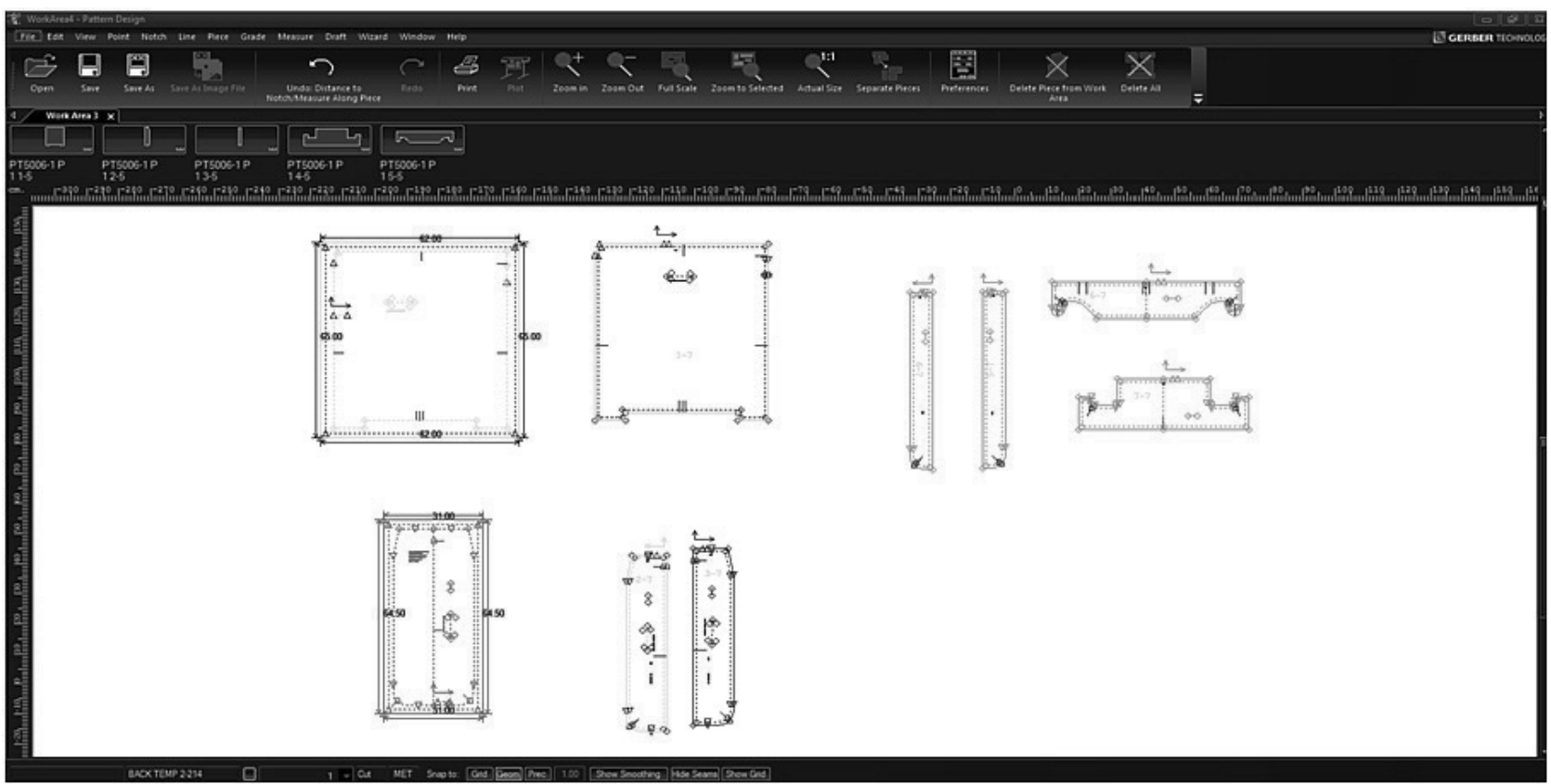

Figure 8: Auxiliary cut markers for cutting parts 1-7, 2-7 and 3-7 for the backrest cover [6]

in the calculation of material consumption. The cutting parts marked in blue (Figure 8 ) are not laminated (only woven fabric), so they will later fit directly into the cut marker used to calculate fabric consumption for the entire cover. This part of the cover seat is made of four types of material: woven fabric, $5 \mathrm{~mm}$ foam, 10 $\mathrm{mm}$ foam and cotton knitted fabric, which means we need to make four cut markers. The calculation of the consumption of woven fabric on the basis of the cut marker is made. Woven fabric with dimensions $\mathbf{1 1 2 , 5}$ $\mathbf{x} 81,5 \mathrm{~cm}$ is needed. This cut marker includes the two auxiliary cut markers (Figure 8 ) and the other parts which are made only of woven fabric. The blue sections are already included in the auxiliary cut markers. A cut marker for the $5 \mathrm{~mm}$ foam covers only one of the auxiliary cut markers, as only cut sections 2-7 and 3-7 are laminated with $5 \mathrm{~mm}$ foam. This cut marker is $\mathbf{6 1 . 5} \times 28 \mathrm{~cm}$ in size. The parts marked in red (Figure 8) are not included in the formation of this cut marker, as they do not contain $5 \mathrm{~mm}$ foam. A cut marker for the $10 \mathrm{~mm}$ foam covers only one of the auxiliary cut markers because only section 1-7 is laminated with $10 \mathrm{~mm}$ foam. According to this cut marker, the consumption of $10 \mathrm{~mm}$ foam is $\mathbf{6 2} \times \mathbf{5 9} \mathrm{cm}$. The parts marked in red (Figure 8) are not included in the formation of this cut marker, they do not contain $10 \mathrm{~mm}$ foam.

A cut marker for a cotton knitted fabric contains only the auxiliary cut markers, as only those three parts are laminated and contain a cotton knitted fabric. When forming this cut marker, attention is paid to the direction of the stretching of the cotton knitted fabric, as well as not to exceed the width of the cot- ton knitted fabric which is $150 \mathrm{~cm}$. This cut marker is $126,5 \times 65 \mathrm{~cm}$ in size. The parts marked in red are not included because they are not laminated, i.e., they do not contain cotton knitted fabric.

\subsection{A cut marker for the legrest cover}

When the sketching is completed and the materials of which the individual zones are composed of are defined, the cutting parts of the legrest cover are made (Figure 9). The cut pieces 1-6, 4-6 and 5-6 are parts that need to be laminated before being cut. We make a special auxiliary cut marker for them in which the direction of stretching of the cotton knitted fabric and the thickness of the foam $(5 \mathrm{~mm})$ is indicated (Figure 10). The cutting parts marked in blue in Figure 10 are not laminated (only woven fabric), so they will later fit directly into the cut marker used to calculate the fabric consumption for the entire cover. Legrest cover is made of three types of material: woven fabric, foam and cotton knit. This means that we need to make three cut markers. The dimensions of the woven fabric are $125 \times 108 \mathrm{~cm}$. This cut marker includes the auxiliary cut marker and the other three parts which are made only of woven fabric. The blue parts are already included in the auxiliary cut marker (Figure 10). A cut marker for a cotton knitted fabric covers only the auxiliary cut marker, because the cut parts in it are laminated and contain cotton knitted fabric. This cut marker is $\mathbf{9 1 , 5 \times 8 4} \mathrm{cm}$ in size. The parts marked in blue are not included because they are not laminated, i.e. they do not contain cotton knitted fabric. The consumption of $5 \mathrm{~mm}$ foam is $\mathbf{8 8 , 5} \times \mathbf{8 1} \mathrm{cm}$. 


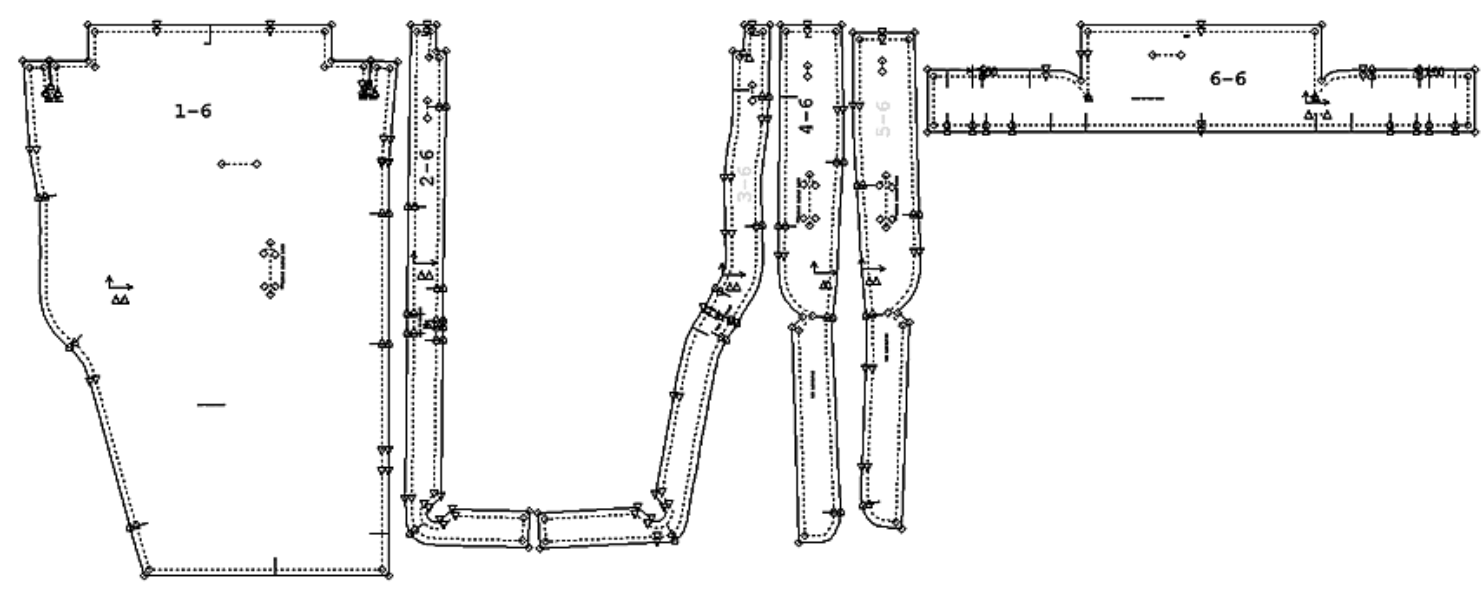

Figure 9: Cutting parts of the legrest cover [6]

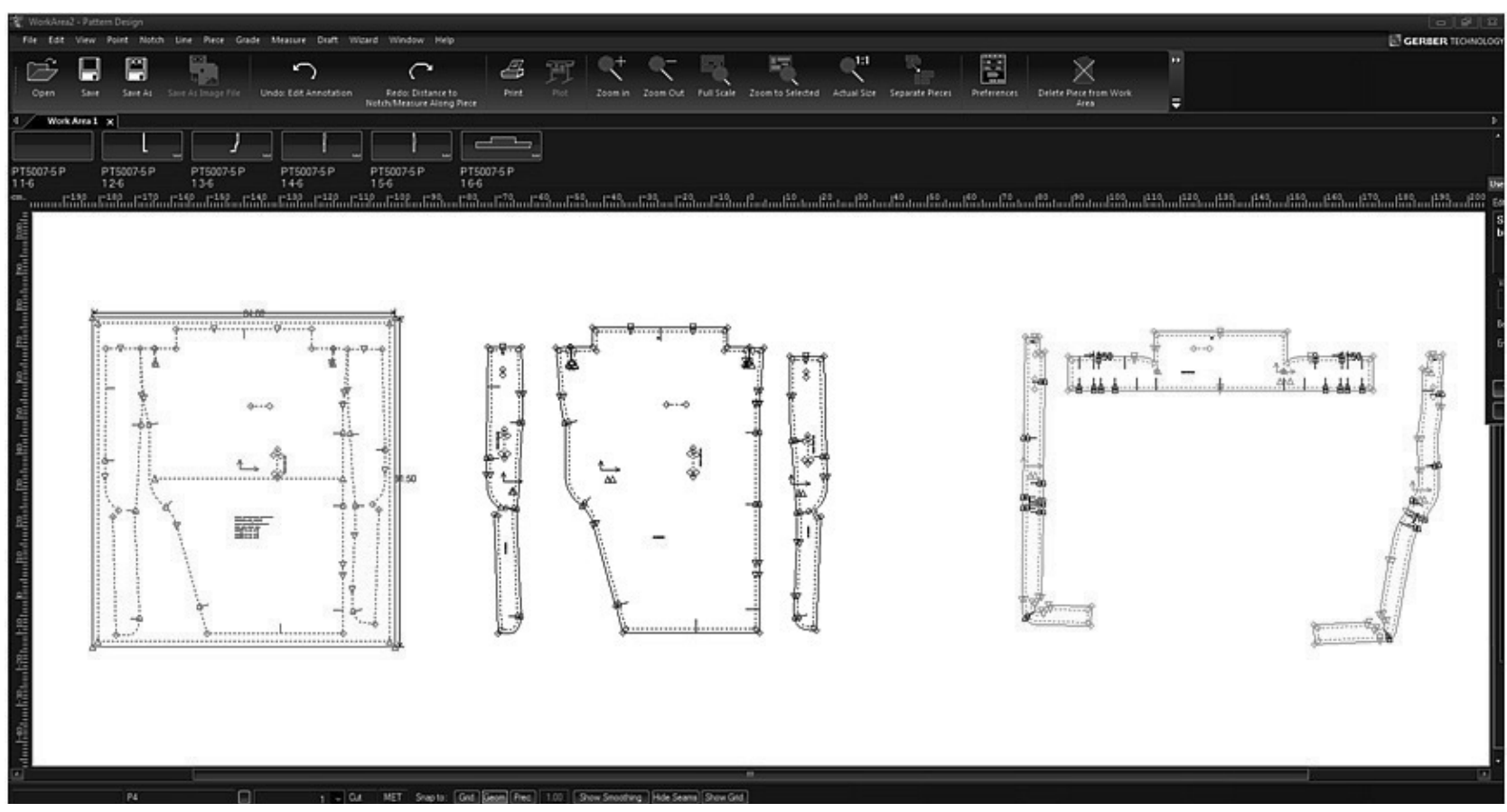

Figure 10: Auxiliary cut marker for cutting parts $1-6,4-6$ and 5-6 on the legrest cover [6]

\section{CONCLUSIONS}

The ergonomic design and quality of the aircraft seat are very important factors that affect the feeling of comfort or discomfort during the flight, especially when it comes to longer trips. This is a complex problem in which experts from many fields participate. The task of textile engineers is to make a cover for the aircraft seat. Based on the designed model, the most appropriate materials should be selected, the cut parts should be made and fit into a cut marker, and tailoring, sewing and finishing should be done. The quality of the textile materials and the leather used in the production, as well as the correctly performed technological process of production determine the quality of the finished product. In this paper the procedure for making a cut marker and calculating the consumption for airplane seat cover material is shown. The process of tailoring and sewing will be the subject of further research.

\section{REFERENCES}

[1] The Art of Garment Manufacturing: Markers, Spreading, and Cutting $\mid$ CottonWorks ${ }^{\mathrm{TM}}$, Increase the power of 3D (http: //optitek.com/solutions/odev/3dproduction-suite/, available: 02/18/2017).

[2] Mausmi, A. (2013) Fabric Utilization, I Cut Order Planning, Stitch World. (https://apparelresources. com//business-news/manufacturing/fabric- 
utilization-i-cut-order-planning/), available: 02/03/2021).

[3] Carr, H.,Latham, B. (2008). Technology of clothing manufacture. Oxford: Blackwell Publishing Ltd United Kingdom, editor: Tyler, D.

[4] Trautman, J.E. (1979). Material utilization in the apparel industry. Arlington: Apparel Research Fondation Inc.

[5] Zhezhova, S., Demboski, G., Srebrenkoska, V., Jordeva, S., Golomeova Longurova, S. (2019). The influence of the type and width of the cut marker on the utilization of textile materials, Advanced Technologies, 8(2), 99-104.
[6] Technical documentation from Sabeti Wain Aerospace-Ltd-High Wycombe-UK.

Primljeno/Received on: $\quad$ 19.04.2021.

Revidirano/ Revised on: 04.05.2021.

Prihvaćeno/Accepted on: 06.05.2021.

(c) 2021 Authors. Published by Union of Textile Engineers and Technicians of Serbia. This article is an open access article distributed under the terms and conditions of the Creative Commons Attribution 4.0 International license (CC BY) (https://creativecommons.org/licenses/by/4.0/) 